\title{
Assessment of terrestrial small mammals and a record of the critically endangered shrew Crocidura wimmeri in Banco National Park (Côte d'Ivoire)
}

\begin{abstract}
This study investigated the small mammal community of the periurban Banco National Park $\left(34 \mathrm{~km}^{2}\right)$, Abidjan, Côte d'Ivoire, using identical numbers of Sherman and Longworth traps. We aimed to determine the diversity and distribution of rodents and shrews in three different habitats: primary forest, secondary forest and swamp. Using 5014 trap-nights, 91 individuals were captured that comprised seven rodent and four shrew species. The trapping success was significantly different for each species, i.e., the Longworth traps captured more soricids (31/36 shrews), whereas the Sherman traps captured more murids ( $37 / 55$ mice). The most frequent species was Praomys cf. rostratus, followed by Crocidura buettikoferi, Hybomys trivirgatus and Crocidura jouvenetae. Indices of species richness $(\mathrm{S})$ and diversity $\left(\mathrm{H}^{\prime}\right)$ were greatest in primary forest, followed by secondary forest and swamp. Several expected species, such as Crocidura obscurior, were not found, whereas we captured four specimens of the critically endangered (IUCN 2012) Wimmer's shrew Crocidura wimmeri, a species that has vanished from its type locality, Adiopodoumé. Therefore, Banco National Park represents an important sanctuary, not only for plants, birds and primates, but also for other small forest vertebrates.
\end{abstract}

Keywords: diversity index; Muridae; small mammal community; Soricidae; threatened species.

\footnotetext{
*Corresponding author: Blaise Kadjo, University of Cocody-Abidjan, UFR Biosciences, Laboratory of Zoology, 22 BP 582 Abidjan 22, Côte d'Ivoire, e-mail: blaisekadjo1@hotmail.com

Roger Yao Kouadio: Ivorian Parks and Reserves Office, 06 BP 426 Abidjan 06, Côte d'Ivoire

Valérie Vogel, Sylvain Dubey and Peter Vogel: Department of Ecology and Evolution, University of Lausanne, CH-1015 Lausanne, Switzerland
}

\section{Introduction}

In Côte d'Ivoire, over $80 \%$ of the primary forest has disappeared because of agriculture and logging (Chatelain et al. 1996). Most of the relics of primary forest are found only in protected areas such as national parks and forest reserves (forêts classées). These fragmented zones represent the last sanctuaries for the protection and conservation of biodiversity (Gonedelé Bi et al. 2006). With the exception of the Taí and Comoé National Parks (southwest and northeast Côte d'Ivoire, respectively), the biodiversity of these protected areas remains poorly documented (Kouadio 2009). This is particularly true for terrestrial small mammals, such as rodents and shrews (Dosso 1983, Churchfield et al. 2004).

Among eight national parks and five natural reserves in the country, Banco National Park (BNP) encompasses an area of $34 \mathrm{~km}^{2}$, situated partially within the metropolis Abidjan. Set up in 1953 by the colonial administration, it is a priceless floristic sample of wet, dense evergreen forest in the south of the country, an isolated part of the Upper Guinea forest of West Africa (Bakarr et al. 2001, Assemian et al. 2006).

Previous studies conducted in BNP were mostly related to botanical censuses (Aké-Assi et al. 1974, De Koning 1983). Very few studies have been concerned with the fauna. An ecological and biological program managed by the Wild Chimp Foundation (WCF) and observations by one of the authors (BK) have confirmed the survival of primate populations, particularly chimpanzees. However, small mammals have only been surveyed in two studies that focused on rodents (Bellier and Gautun 1968, Adam 1977). Thus, a detailed survey of the small mammal community in BNP is still needed. Scientists at the former French scientific station (ORSTOM) in the Adiopodoumé forest (AF), a site $15 \mathrm{~km}$ from BNP, identified several new species, making Adiopodoumé the type locality for Doucet's musk shrew Crocidura douceti Heim de Balsac, 1958 and Baer's wood mouse, Hylomyscus baeri Heim de Balsac and Aellen, 1965. The most enigmatic, and highly endemic species, from that type locality is Wimmer's shrew C. wimmeri Heim de Balsac and Aellen, 1958. Today, $\mathrm{AF}$ is strongly degraded and partially lost due to the combined effects of logging and farming, the lack of protection status and urban pressure from the expanding city of Abidjan. 
Our study focussed on the small mammal community of the BNP, especially families Muridae and Soricidae, to determine their associations with primary forests and secondary forests and swamp and to determine whether any of the rare species recorded at AF have survived in this sanctuary. Drift fences combined with pitfalls appear to be the best technique in rainforest habitats (Goodman et al. 2001, Barrière et al. 2005, Nicolas and Colyn 2006, Gambalemoke et al. 2008a,b), but this method has been prohibited to avoid any disturbance of the wild chimpanzee population in this small park. Therefore, we used two types of live traps to facilitate a more exhaustive sampling of the terrestrial small mammal community.

\section{Material and methods}

\section{Study area}

BNP $\left(5^{\circ} 21^{\prime}-5^{\circ} 25^{\prime} \mathrm{N} ; 4^{\circ} 01^{\prime}-4^{\circ} 05^{\prime} \mathrm{W}\right)$ contains about $34 \mathrm{~km}^{2}$ of remnant rainforest (Mangenot 1955, Aké-Assi et al.
1974), and it is located in Abidjan, where it is surrounded by urban areas. Only the northwestern limit is adjacent to open landscape (Figure 1). The climate is tropical, and it is characterized by four seasons, with an average annual rainfall of about $2000 \mathrm{~mm}$, and an annual average temperature of $26.4^{\circ} \mathrm{C}$. The dry season lasts from December to March and is followed by the period of highest precipitation (main rainy season) from March to July. A minor rainy season lasts from October to November.

\section{Trapping design}

Our field survey was conducted between November 2007 and January 2008 with a total of 5014 trap-nights. Small mammals were sampled using two types of live traps: (i) Sherman traps (type SFA, H.B. Sherman Traps, Inc., Tallahassee, FL, USA), with entrance dimensions of $5.5 \times 7 \mathrm{~cm}$, and (ii) Longworth traps (Penlon Ltd., Oxford, UK), with entrance dimensions of $4.5 \times 4.5 \mathrm{~cm}$ and a nest chamber that can be filled with hay.

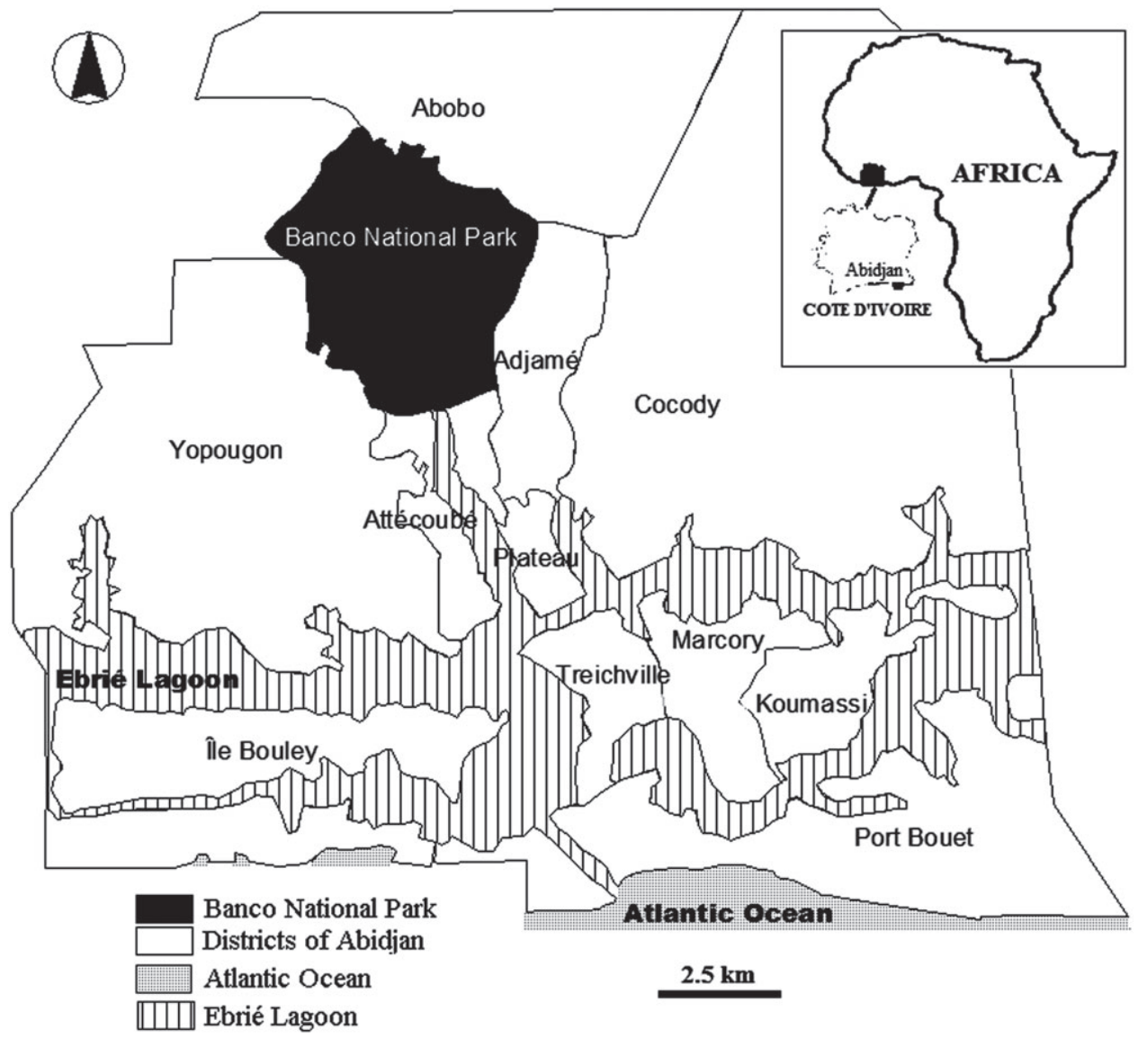

Figure 1 Map of Abidjan district with Banco National Park in the north. 
Twelve plots, each with an area of 5 ha, were selected and sampled randomly in primary forest, secondary forest and swamp.

The traps were baited with fresh palm nut shavings (Elaeis guinneensis) and smoked fish. Each transect or trap line contained 25 Sherman and 25 Longworth traps per station that were spaced 5-10 m apart and, where possible, placed close to structural complexities, e.g., at the base of a tree, along a fallen trunk or sometimes on a thick branch. Trapping was performed over 4 consecutive days, and the traps were checked daily and rebaited as necessary.

The captured animals were identified, sexed and standard measures were recorded. Animals that were not identifiable in the field were autopsied and kept as voucher specimens. Tissue samples were saved from all of those specimens, which were preserved in ethanol $(90 \%)$ and deposited at the Laboratory of Zoology at University of Cocody-Abidjan (Côte d'Ivoire). The fieldwork was initiated by PV and conducted by BK and RYK. The rodents were identified by BK and PV based on morpho-anatomical data and a comparative specimen collection.

Taxonomy followed Happold (1977), Wilson and Reeder (2005), with modifications for Hylomyscus and Praomys following Quérouil et al. (2001) and Nicolas et al. (2005, 2006, 2008, 2010b), and for Mastomys and Mus following Denys et al. (2005) and Kouassi Kan et al. (2010). This taxonomy is challenging due to a lot of sibling species (Taylor 2000). All of the shrews were identified by molecular analyses performed by VV and SD.

\section{Data and statistical analyses}

To standardize data for all sites sampled, the trapping success (T) was calculated as the number of captured individuals/100 trap nights: $T=\{n / E\} \times 100$, where $n$ is the number of small mammals trapped, and $\mathrm{E}$ is the number of traps checked. To describe the overall characteristics of the small mammal communities, we used the ShannonWiener index $\left(\mathrm{H}^{\prime}\right)$, Simpson's diversity index (1-D), evenness and equitability indexes and the Chao2 estimator based on the presence or absence of data (Colwell 2000). For both live trap models, we compared the number and identity of species captured. Chi-square tests $\left(\chi^{2}\right)$ were used for trap success comparisons. The weight distribution of mammals was compared using Wilcoxon's rank sum test to test for any possible selectivity with both trap types. All statistical analyses were performed using XLSTAT 7.1 and the "R" Statistical package version 2.5.1. (http://www.r-project.org).

\section{Results}

\section{Species composition}

During 11 weeks, 5014 trap nights were conducted in the three habitats, and 91 terrestrial mammals were captured (Table 1). Captured mammals belonged to two families in two orders: 36 soricids (Soricomorpha: Soricidae), represented by five species, and 55 murids (Rodentia: Muridae), represented by seven species. The four most frequent species comprised $72.2 \%$ of the captures: Praomys cf.rostratus Miller, 1900 was the most abundant rodent species, followed by Hybomys trivirgatus Temminck, 1853. Crocidura buettikoferi Jentink, 1888 was the most abundant shrew, followed by Crocidura jouvenetae Heim de Balsac, 1958. The remaining species (27.8\%) each represented less than $10 \%$ of the mammals captured, i.e., the murids Malacomys edwardsi Rochebrune, 1885, Hylomyscus alleni (Waterhouse, 1838), Dephomys defua (Miller, 1900), Mastomys natalensis (Smith, 1834), Lophuromys sikapusi (Temminck, 1853) and the shrews Crocidura olivieri (Lesson, 1827) and Crocidura wimmeri. The capture of four Wimmer's shrews was the most important result in this study.

\section{Habitat preference and species distribution}

The diversity indexes (Table 1) showed that the small mammal community in the primary forest had the highest species richness $(\mathrm{S}=13)$ and the highest diversity index $\left(\mathrm{H}^{\prime}=2.048\right.$; Chao2=42.75), followed by the secondary forest $\left(\mathrm{S}=8, \mathrm{H}^{\prime}=1.873\right.$; Chao2=11.12) and the swamp $(\mathrm{S}=6$, $\mathrm{H}^{\prime}=1.445$; Chao2=11.84). The Mann-Whitney test (with Bonferroni's correction) detected a significant difference in the diversities of the three habitats $\left(\mathrm{H}_{\mathrm{c}}=6.925, \mathrm{p}=0.036\right)$. The equitability was lower in the primary forest $(0.85)$ than the secondary forest and swamp (both 0.90).

In the primary forest, the small mammal community was dominated by Praomys cf. rostratus (35.5\% of all captures, $\mathrm{n}=16, \mathrm{~T}=0.67 \%$ ). Among the rare species, Dephomys defua and Crocidura wimmeri (with three captures) were associated with this habitat. In the secondary forest, Hybomys trivirgatus and Crocidura buettikoferi (both $\mathrm{n}=8$, $\mathrm{T}=0.49 \%)$ were the most abundant species. They were followed by Crocidura jouvenetae, which had a capture rate three times higher in secondary forest than the other habitats $(\mathrm{T}=0.37 \%)$. In the swamp, the community was dominated by $P$. cf. rostratus ( $\mathrm{T}=0.41 \%$ ) and $C$. buettikoferi $(\mathrm{T}=0.41 \%)$. Malacomys edwardsi had a higher capture rate in swamp ( $\mathrm{T}=0.20 \%)$ than in the other habitats. 
Table 1 Diversity and relative abundance of Murids and Soricids trapped in Banco National Park during three months from November 2007 to January 2008 (5014 trap nights).

\begin{tabular}{|c|c|c|c|c|c|c|c|c|}
\hline Trap-nights & $\begin{array}{r}\begin{array}{r}\text { Primary } \\
\text { forest }\end{array} \\
2393\end{array}$ & $\mathrm{~T}(\%)$ & $\begin{array}{r}\begin{array}{r}\text { Sec. } \\
\text { forest }\end{array} \\
1631\end{array}$ & $\mathrm{~T}(\%)$ & $\begin{array}{r}\text { Swamp } \\
985\end{array}$ & $\mathrm{~T}(\%)$ & $\begin{array}{l}\text { Total } \\
5014\end{array}$ & $\begin{array}{r}\text { Rel. } \\
\text { abundance (\%) }\end{array}$ \\
\hline \multicolumn{9}{|l|}{ Soricidae } \\
\hline Crocidura buettikoferi & 7 & 0.29 & 8 & 0.49 & 4 & 0.41 & 19 & 20.80 \\
\hline Crocidura jouvenetae & 3 & 0.13 & 6 & 0.37 & 1 & 0.10 & 10 & 10.99 \\
\hline Crocidura wimmeri & 3 & 0.13 & 1 & 0.06 & 0 & 0.00 & 4 & 4.40 \\
\hline Crocidura olivieri & 3 & 0.13 & 0 & 0.00 & 0 & 0.00 & 3 & 3.30 \\
\hline Total Soricidae & 16 & 0.67 & 15 & 0.92 & 5 & 0.51 & 36 & 39.56 \\
\hline \multicolumn{9}{|l|}{ Muridae } \\
\hline Praomys cf rostratus & 16 & 0.67 & 5 & 0.31 & 4 & 0.41 & 25 & 27.47 \\
\hline Hybomys trivirgatus & 3 & 0.13 & 8 & 0.49 & 0 & 0.00 & 11 & 12.09 \\
\hline Malacomys edwardsi & 3 & 0.13 & 2 & 0.12 & 2 & 0.20 & 7 & 7.69 \\
\hline Hylomyscus alleni & 2 & 0.08 & 2 & 0.12 & 1 & 0.10 & 5 & 5.49 \\
\hline Dephomys defua & 3 & 0.13 & 0 & 0.00 & 0 & 0.00 & 3 & 3.30 \\
\hline Mastomys natalensis & 1 & 0.04 & 2 & 0.12 & 0 & 0.00 & 3 & 3.30 \\
\hline Lophuromys sikapusi & 1 & 0.04 & 0 & 0.00 & 0 & 0.00 & 1 & 1.10 \\
\hline Total Muridae & 29 & 1.21 & 19 & 1.16 & 7 & 0.71 & 55 & 60.44 \\
\hline Number of species (S) & 11 & & 8 & & 5 & & & \\
\hline Total T & & 1.88 & & 2.08 & & 1.22 & & \\
\hline \multicolumn{9}{|l|}{ Diversity indexes } \\
\hline Shannon-Wiener & 2.05 & & 1.87 & & 1.45 & & & \\
\hline Simpson & 0.82 & & 0.83 & & 0.74 & & & \\
\hline Evenness & 0.70 & & 0.81 & & 0.85 & & & \\
\hline Equitability J & 0.85 & & 0.90 & & 0.90 & & & \\
\hline Chao2 $(S * 2)$ & 42.75 & & 11.12 & & 11.84 & & & \\
\hline
\end{tabular}

$\mathrm{T}$, trap success.

\section{Comparative trap success}

Only 91 terrestrial mammals were captured during 5014 trap nights (Table 1), a trapping success of $1.81 \%$. The overall capture success was similar for the two trapping systems (Longworth: 49 captures, $\mathrm{T}=1.95 \%$; Sherman: 42 captures, $\mathrm{T}=1.68 \%$ ). However, the trapping efficiency for shrews was significantly higher with the Longworth traps (31 individuals with Longworth versus 5 with the Sherman traps, $\left.\chi^{2}=13.86, \mathrm{df}=1, \mathrm{p}<0.001\right)$. For murids, the trapping efficiency was higher with the Sherman traps (37 individuals versus 18 with the Longworth traps, $\chi^{2}=4.65, \mathrm{df}=1$, $\mathrm{p}<0.05$ ). The body weight distribution (Figure 2) was significantly different in the two trap types (Wilcoxon rank sum test, $\mathrm{W}=346.5, \mathrm{p}<0.001$ ). The Longworth traps appear to have a higher trapping success for species with low body masses, such as shrews, whereas the Sherman traps appear to be more suitable for heavier species (e.g., mice and rats).

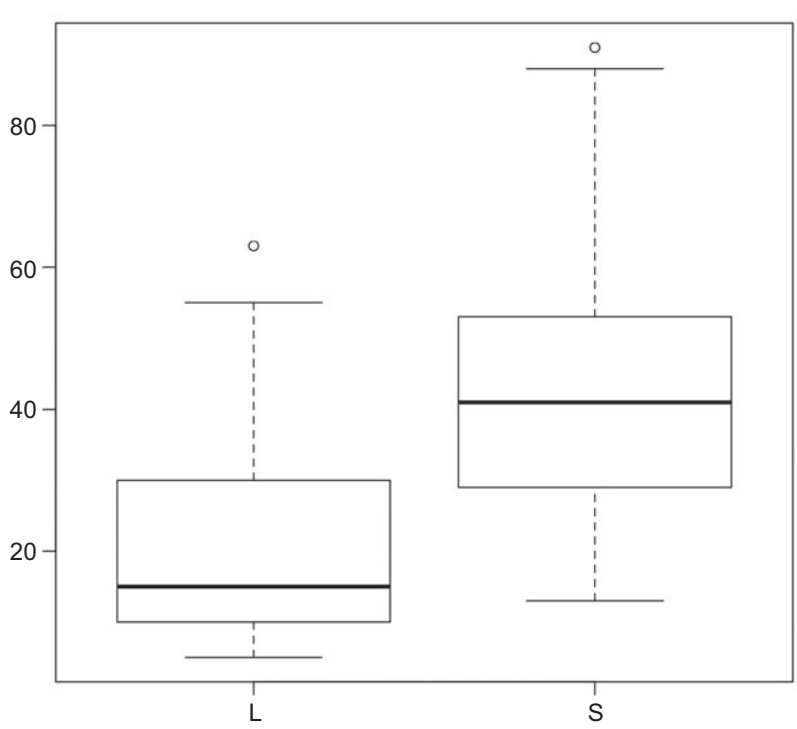

Figure 2 Box plot of the weight [g] of the small mammals captured by Longworth (L) and by Sherman (S) traps. 


\section{Discussion}

\section{Shrew species in BNP}

The most important species captured was Wimmer's shrew Crocidura wimmeri. Previously, this species was known only from Adiopodoumé forest (Heim de Balsac and Aellen 1958, Vogel 1976, Vogel et al. 1981, Meylan and Vogel 1982), and several attempts to find new specimens for a genetic study failed (PV, personal observation). This highly endemic shrew is listed as a critically endangered species in category B1ab (iii), which concerns species with distribution areas that are probably less than $100 \mathrm{~km}^{2}$ (IUCN 2012). It is among the 794 most threatened species in the world and the 10 most threatened vertebrates in Côte d'Ivoire (Alliance for Zero Extinction 2012). Habitat deterioration at the former ORSTOM station (now the Centre National de Recherche Agronomique) due to woodcutting may explain this shrew's extinction at the type locality.

The most frequent species was Crocidura buettikoferi, a common shrew that also lives in agricultural habitats in the region of Abidjan. Crocidura jouvenetae was also a ubiquitous species, although it was clearly associated with secondary forest. Crocidura olivieri was only found in primary forest, although this is usually the most frequent species in villages and the agricultural landscape, where it is often present at a high density (Kadjo et al. 1996, Lim and Van de Groot Coeverden 1997, Decher et al. 2005, Nicolas et al. 2009). It is widespread throughout much of Africa, where it is characterized by many genetic lineages (Dubey et al. 2007).

Unexpectedly, Crocidura douceti and Crocidura muricauda (Miller, 1900) were not captured, although both are known from AF. Another species that we did not find in BNP was Crocidura obscurior, which is well known from AF (Meylan 1971, Hunkeler 1973, Vogel et al. 1981) and also found $125 \mathrm{~km}$ west in Azagny National Park (Kang et al. 2011). However, the traps used in this study were probably not suitable for capturing this small shrew species (Vogel 2012) because previous successful captures used pitfall traps (Vogel et al. 1981). Our study also failed to capture Crocidura theresae Heim de Balsac 1968, which is trapped frequently $40 \mathrm{~km}$ to the west near Dabou (Meylan 1971), or the rare Sylvisorex megalura (Jentink 1888). According to Vogel (1974) and Meylan (1975), these species may be limited to the coastal savannah. Other forest species known from Taí forest and Nimba Mountain in Côte d'Ivoire that were also absent in the Abidjan region or AF were Crocidura nimbae Heim de Balsac, 1956, Crocidura grandiceps Hutterer, 1983 and Crocidura lamottei Heim de Balsac, 1968.

\section{Murid species in BNP}

Both of the trap types used in this study limited rodent captures to the smaller Muridae, excluding adult Rattus rattus. Cricetomyidae, Sciuridae and arboreal dormice (Gliridae) were not captured.

Previously, the most frequent murid in BNP was considered to be Praomys tullbergi, but due to the discovery of Praomys rostratus as a more common sympatric sibling species in this region (Akpatou et al. 2007, Nicolas et al. 2008, 2010a), we prefer to use the name Praomys cf. rostratus for captured individuals. Praomys specimens cannot be determined easily without genetic analysis. The next most common species, Hybomys trivirgatus, was most frequent in secondary forest and also frequent in AF (Hunkeler 1973). Malacomys edwardsi was trapped in all three habitats, although most frequently in swamp. Dephomys defua is a primary forest species (Rosevear 1969). By contrast, Mastomys natalensis and Lophuromys sikapusi are present at the intersections between agricultural land and secondary forests, and they have been trapped regularly in Adiopodoumé. In Côte d'Ivoire, Mastomys erythroleucus has been sampled at low frequencies in forest zones (Kouassi Kan 2010). Lecompte et al. (2006) trapped ten times more $M$. natalensis than $M$. erythroleucus in Guinea.

Also absent were Mus (Nannomys) setulosus Peters, 1876 and Mus (Nannomys) minutoides (Smith, 1834); both prefer rather open landscapes (agricultural land near Adiopodoumé and Dabou). Surprisingly, the forest species Hylomyscus baeri Heim de Balsac, 1965, Hylomyscus alleni (Waterhouse, 1838) and Grammomys poensis Eisentraut, 1965 were absent. However, these partly arboreal species were probably not sampled because all of the traps were set at ground level (Dosso 1988). Moreover, Malacomys cansdalei Ansell, 1958, which was trapped in BNP by Bellier and Gautun (1968), was not observed. The species accumulation curve for all three habitats (not shown) indicated that other species might still be found.

\section{Species richness and diversity}

In the three different habitats, our results confirmed the classical view of decreasing species richness in primary forest through secondary forest to swamp (Turner and Corlett 1996, Gardner et al. 2007). This was confirmed by Shannon's index of diversity $\left(\mathrm{H}^{\prime}\right)$. The trapping success was also significantly lower in swamp, which indicates a 
lower population density that might be explained by the limited potential for population growth due to flooding.

The classical diversity indices are rarely useful for comparing different regions due to different sampling techniques. Therefore, a simple comparison of species richness (S) can be used. At BNP, $\mathrm{S}=4$ for soricids, and $\mathrm{S}=7$ for murids. Compared with other parks in Côte d'Ivoire, this species richness was very low. In Taí National Park, the value for soricids is $S=10$, whereas that for murids is $\mathrm{S}=19$. At Mount Nimba Reserve, the values are 11 and 15, respectively (Dosso 1975, 1988, Churchfield et al. 2004, Decher et al. 2005). Perhaps the coastal forest of which BNP is part is rather species poor. Moreover, its surface is small $\left(34 \mathrm{~km}^{2}\right)$ compared with the Mount Nimba Reserve $\left(50 \mathrm{~km}^{2}\right)$ or the Taí National Park $\left(3300 \mathrm{~km}^{2}\right)$. The diversity of habitats is higher in both of these protected areas due to the presence of several river systems and their more complex geomorphology.

\section{Conclusion}

This study updates the terrestrial small mammal list for BNP and confirms its important function as a sanctuary in this increasingly urbanized West African region. The vertebrates of concern include small mammals and amphibians as well as primates, especially chimpanzees. Endemic species are particular important, such as the newly discovered frog genus (Astylosternus) reported by Assemian et al. (2006) and the rediscovered endemic Wimmer's shrew Crocidura wimmeri, which are both highly threatened by ongoing urbanization (Mcdonald et al. 2008). These issues are important arguments for keeping BNP under strict protection to maintain its role as a vertebrate sanctuary for future generations. The persistence of human-induced disturbance is a major challenge for most of the protected areas in Africa (Nicolas et al. 2010c).

Acknowledgements: We thank the Ivorian Parks and Reserves Office, Abidjan for permission and access to the BNP and also Drs Mamadou Ouattara and Sery Bi Gonedelé for their assistance with drawing the maps. We are also grateful to Prof. Kouassi Kouassi Philippe. We extend our thanks to Hilaire Aké and Amara Bamba for their assistance in the field. Peter Vogel acknowledges the authorization for his research activity by Prof. Samuel Gadegbeku, the Centre Suisse de Recherches Scientifiques for hospitality and the Herbette Foundation, University of Lausanne, for a financial contribution.

Received July 9, 2012; accepted February 19, 2013

\section{References}

Abi-Boutros, B. and L. Bellier. 1977. Contribution à la taxinomie des Micromammifères. Application au genre Crocidura (Crocidures). Cah. Anal. Donn. 2: 435-450.

Adam, F. 1977. Données préliminaires sur l'habitat et la stratification des rongeurs en forêt de basse Côte d'Ivoire. Mammalia 41: 283-290.

Aké-Assi, L., E. Adjanohoun and H. Camefort. 1974. Les milieux naturels en Afrique intertropicale et à Madagascar. Tome IV: ecologie des forêts denses humides-la Forêt du Banco. UNESCO, Paris, France. pp. 63.

Akpatou, K.B., V. Nicolas, D. Pires and E. N'goran. 2007. Morphometric differentiation between two rodents, Praomys tullbergi (Thomas, 1894) and Praomys rostratus (Miller, 1900), in West Africa. Zootaxa 1607: 21-34.

Alliance for Zero Extinction. 2012. American bird conservancy. Alliance for Zero Extinction, Washington, DC. Available at http://www.zeroextinction.org. Accessed on 12 June 2012.

Assemian, N.E., N.G. Kouamé, B. Tohé, G. Gourène and M.O. Rödel. 2006. The anurans of the Banco National Park, Côte d'Ivoire, a threatened West African rainforest. Salamandra 42: 41-51.

Bakarr, M., B. Baley, D. Byler, R. Ham, S. Olivieri and M. Omland. 2001. From the forest to the sea: biodiversity connections from Guinea to Togo. Conservation Priority-Setting Workshop,
December 1999. Conservation International, Washington, DC. pp. 78.

Barrière, P., R. Hutterer, V. Nicolas, S. Quérouil and M. Colyn. 2005. Investigating the role of natural gallery forests outside the Congolese rainforest as a refuge for African forests shrews. Belg. J. Zool. 135(Suppl.): 21-29.

Bellier, L. and J.C. Gautun. 1968. A propos des Malacomys longipes en Côte d'Ivoire. Mammalia 32: 72-81.

Chatelain, C., L. Gauthier and R. Spichiger. 1996. A recent history of forest fragmentation in southwestern Côte d'Ivoire. Biodiv. Cons. 5: 37-53.

Churchfield, S., P. Barrière, R. Hutterer and M. Colyn. 2004. First results on the feeding ecology of sympatric shrews (Insectivora: Soricidae) in the Taí National Park, Côte d'Ivoire. Acta Theriol. 49: 1-15.

Colwell, R.K. 2000. Estimate S, statistical estimation of species richness and shared species from samples. Version 6.0. Available at: http://Uconn.edu/estimates. Accessed on 21 December 2011.

Decher, J., B. Kadjo, M.L. Abedi, O.T. Elhadji and K. Soumaoro. 2005. Une étude rapide des petits mammifères (musaraignes, rongeurs et chiroptères) des forêts classées de la haute Dodo et du Cavally, Côte d'Ivoire. In: (F. Lauginie, G. Rondeau 
and L.E. Alonso, eds.) A rapid biological assessment of two classified forests in South-Western Côte d'Ivoire. RAP Bulletin 34. Conservation International, Washington, DC. pp. 91-109.

Decher, J., R.W. Norris and J. Fahr. 2010. Small mammal survey in the upper Seli River Valley, Sierra Leone. Mammalia 74: 163-176.

De Koning, J. 1983. La Forêt du Banco. Veenman. \& Zonen, Wageningen. pp. 156.

Denys, C., E. Lecompte, E. Calvet, M.D. Camara, A. Doré, K. Koulémou, F. Kourouma, B. Soropogui, O. Sylla, B. AllaliKouadio, S. Kouassi Kan, C. Akoua-Koffi, J. Ter Meulen and L. Koivogui. 2005. Community analysis of Muridae (Mammalia, Rodentia) diversity in Guinea: a spatial emphasis on Mastomys species and Lassa fever distributions. In: (B.A. Huber, B.J. Sinclair and K.H. Lampe, eds.) African biodiversity. Molecules, organisms, ecosystems. Springer, Berlin. pp. 339-350.

Dosso, H. 1975. Liste préliminaire des rongeurs de la forêt de Taí ( $5^{\circ} 53^{\prime} \mathrm{N}$ et $7^{\circ} 23^{\prime} \mathrm{W}$ ) Côte d'Ivoire. Mammalia 75: 515-517.

Dosso, H. 1983. Etude des Rongeurs de forêts hygrophiles conservées et des zones anthropisées de la Côte d'Ivoire méridionale. PhD dissertation. University of Abidjan, Abidjan, Côte d'Ivoire. pp. 249.

Dosso, H. 1988. Les peuplements de rongeurs de forêts et des zones défrichées et cultivées de la Côte d'Ivoire. Ann. Univ. Abidjan SE (Ecol.) 20: 67-85.

Dubey, S., M. Antonin, C. Denys and P. Vogel. 2007. Use of phylogeny to resolve the taxonomy of the widespread and highly polymorphic African giant shrews (C. olivieri group, Crocidurinae, Mammalia). Zoology 110: 48-57.

Dubey, S., N. Salamin, M. Ruedi, P. Barrière, M. Colyn and P. Vogel. 2008. Biogeographic origin and radiation of the Old World crocidurine shrews (Mammalia, Soricidae) inferred from mitochondrial and nuclear genes. Mol. Phyl. Evol. 48: 953-963.

Gambalemoke, M., I. Mukinzi, D. Amundala, G.B. Katuala, J. Kennis, A. Dudu, R. Hutterer, P. Barrière, H. Leirs and E. Verheyen. 2008a. Shrew trap efficiency: experience from primary forest, secondary forest, old fallow land and old palm plantation in the Congo River basin (Kisangani, Democratic Republic of Congo). Mammalia 72: 203-212.

Gambalemoke, M., I. Mukinzi, D. Amundala, T. Gembu, K. Kaswera, G.B. Katuala, A. Dudu, P. Barrière, M. Colyn, R. Hutterer, J. Kennis, H. Leirs, B. Vanlinde and E. Verheyen. 2008b. Microgeographical distribution of shrews (Mammalia, Soricidae) in the Congo river basin (Kisangani, D.R. Congo). Mammalia 72: 213-222.

Gardner, T.A., M.A.J. Ribeiro, J. Barlow, T.C. Sauer Avila-Pires, M.S. Hoogmoed and C.A. Peres. 2007. The value of primary, secondary, and plantation forests for a neotropical herpetofauna. Conserv. Biol. 21: 775-787.

Goodmann, S.M., R. Hutterer and P.R. Ngnegueu. 2001. A report on the community of shrews (Mammalia: Sorididae) occurring in the Minkébé Forest, northeastern Gabon. Mamm. Biol. 66: 22-34.

Gonedelé Bi, S., D. Zimer, I. Koné, Z. Goné Bi, B.K. Akpatou, J.C. Koffi Bene, A. Sangaré and C. Boesch. 2006. A West African black-and-white colobus monkey, Colobus polykomos Dollmani Schartz, 1927, facing extinction. Primate Conserv. 21: 55-61.

Happold, D.C.D. 1977. A population study on small rodents in the tropical rain forest of Nigeria. Terre et Vie 31: 385-455.

Heim de Balsac, H. 1958. La réserve naturelle intégrale du Mont Nimba. 14. Mammifères Insectivores. Mémoires de L'Institut Fondamentale d'Afrique Noire 53: 301-337.
Heim de Balsac, H. and V. Aellen. 1958. Les Soricidae de basse Côte d'Ivoire. Rev. Suisse Zool. 65: 921-955.

Heim de Balsac, H. and V. Aellen. 1965. Les Muridés de basse Côte d'Ivoire. Rev. Suisse Zool. 72: 695-753.

Hunkeler, P. 1973. Les Cestodes parasites de petits mammifères (Rongeurs et Insectivores de Côte d'Ivoire et de Haute-Volta). Rev. Suisse Zool. 80: 809-930.

Hutterer, R. 2005. Order Soricomorpha. In: (D.E. Wilson and D.M. Reeder, eds.) Mammal species of the world: a taxonomic and geographic reference. The Johns Hopkins University Press, Baltimore, MD. pp. 220-311.

IUCN 2012. IUCN Red list of threatened species. IUCN, Gland, Switzerland and Cambridge, UK. Available at: http:// www. redlist.org/search-expert.php.IUCN species survival commission, Accessed on 18 June, 2012.

Kadjo, B., H. Dosso and R. Vuattoux. 1996. Influence de la végétation sur le peuplement des rongeurs dans la région centre de Côte d'Ivoire. Agronomie Afr. 8: 169-180.

Kang, H.J., B. Kadjo, S. Dubey, F. Jacquet and R. Yanagihara. 2011. Molecular evolution of Azagny virus, a newfound hantavirus harbored by the West African pygmy shrew (Crocidura obscurior) in Côte d'Ivoire. Virology J. 8: 373.

Kouadio, Y.R. 2009. Diversité des rongeurs et insectivores du Parc National du Banco. Mémoire de DEA. Université de Cocody, Côte d'Ivoire. pp. 76.

Kouassi Kan, S., V. Nicolas, V. Aniskine, A. Lalis, C. Cruaud, A. Couloux, M. Colyn, M. Dosso, L. Koivogui, C. Akoua-Koffi and C. Denys. 2008. Taxonomy and biogeography of the African Pigmy mice, subgenus Nannomys (Rodentia, Murinae, Mus). Mammalia 72: 223-228.

Kouassi Kan, S. 2010. Biogéographie, habitat et taxonomie moléculaire des rongeurs réservoirs d'Arénavirus en Côte d'Ivoire. PhD Dissertation. University of Abidjan-Cocody, Abidjan, Côte d'Ivoire. pp. 144.

Lecompte, E., E. Fichet-Calvet, S. Daffis, K. Koulémou, O. Sylla, F. Kourouma, A. Doré, B. Soropogui, V. Aniskine, B. Allali, S. Kouassi Kan, A. Lalis, L. Koivogui, S. Günther, C. Denys and J. TerMeulen. 2006. Mastomys natalensis and Lassa fever, West Africa. Emerg. Infect. Dis. 12: 1971-1974.

Lim, B.K. and P.J. Van de Groot Coeverden. 1997. Taxonomic report of small mammals from Côte d'Ivoire. J. Afr. Zool. 111: 261-279.

Mangenot, G. 1955. Etude sur les forêts des plaines et de plateau de la Côte d'Ivoire. Etudes éburnéennes. Institut D'afrique Noire Centre De Cote D'ivoire, Abidjan, Côte d'Ivoire. pp.61.

Mcdonald, R.I., P. Kareiva and T.T. Forman. 2008. The implication of current and future urbanization for global protected areas and biodiversity conservation. Biol. Conserv. 141: 1695-1703.

Meylan, A. 1971. Chromosomes de soricidés de Côte d'Ivoire (Mammalia, Insectivora). Rev. Suisse Zool. 78: 603-613.

Meylan, A. 1975. Formule chromosomique de Sylvisorex megalura (Jentink) (Mammalia, Insectivora). Mammalia 39: 319-320.

Meylan, A. and P. Vogel. 1982. Contribution à la cytotaxonomie des Soricidés (Mammalia, Insectivora) de l'Afrique occidentale. Cytog. Cell. Gen. 34: 83-92.

Nicolas, V., E. Verheyen, W. Verheyen, J. Hulselmans, M. Dillen, B. Akpatou, A. Dudu, W. Wendelen and M. Colyn. 2005. Systematics of African lowland rainforest Praomys (Rodentia: Muridae) based on molecular and craniometrical data. Zool. J. Linnean Soc. 145: 539-553. 
Nicolas, V. and M. Colyn. 2006. Relative efficiency of three types of small mammal traps in an African rainforest. Belg. J. Zool. 136: 107-111.

Nicolas, V., S. Quérouil, E. Verheyen, J. F. Mboumba, M. Dillen and M. Colyn. 2006. Mitochondrial phylogeny of African wood mice, genus Hylomyscus (Rodentia, Muridae): implications for their taxonomy and biogeography. Mol. Phylogenet. Evol. 38: 779-793.

Nicolas, V., J. Bryja, B. Akpatou, A. Konecny, E. Lecompte, M. Colyn, A. Lalis, A. Couloux, C. Denys and L. Granjon. 2008. Comparative phylogeography of two sibling species of forestdwelling rodent (Praomys rostratus and $P$. tullbergi) in West Africa: different reactions to past forest fragmentation. Mol. Ecol. 17: 5118-5134.

Nicolas, V., P. Barriére, A. Tapiero and M. Colyn. 2009. Shrew species diversity and abundance in Ziama Biosphere Reserve, Guinea: comparison among primary forest, degraded forest and restoration plots. Biodiversity Conserv. 18: 2043-2061.

Nicolas, V., B. Akpatou, W. Wendelen, J.K. Peterhans, A. Olayemi, J. Decher, A.D. Missoup, C. Denys, P. Barrière, C. Cruaud and M. Colyn. 2010a. Molecular and morphometric variation in two sibling species of the genus Praomys (Rodentia: Muridae): implication for biogeography. Zool. J. Linnean Soc. 160: 397-419.

Nicolas, V., A. Olayemi, W. Wendelen and M. Colyn. 2010b. Mitochondrial DNA and morphological identification of a new species of Hylomyscus (Rodentia: Muridae) from West Africa. Zootaxa 2579: 30-44.

Nicolas, V., A. Natta, P. Barrière, A. Delapre and M. Colyn. 2010c. Terrestrial small mammal diversity and abundance in central Benin: comparison between habitats, with conservation implication. Afr. J. Ecol. 48: 1092-1104.

Rosevear, D.R. 1969. The rodents of West Africa. Trustees of the British Museum (Natural History), London, UK. pp. 604.

Taylor, P.J. 2000. Pattern of chromosomal variation in southern African rodent. J. Mammal. 81: 317-331.

Turner, I.M. and R.T. Corlett. 1996. The conservation value of small isolated fragments of lowland tropical rain forest. Trends Ecol. Evol. 11: 330-333.

Vogel, P. 1974. Note sur le comportement arboricole de Sylvisorex megalura (Soricomorpha, Insectivora). Mammalia 38: 171-176.

Vogel, P. 1976. Energy consumption of European and African Shrews. Acta Theriol. 21: 195-206.

Vogel, P. 2012. New trapping method to survey for presence of the Etruscan Shrew Suncus etruscus, the smallest mammal. Mamm. Rev. 42: 314-318.

Vogel, P., M. Genoud and H. Frey. 1981. Rythme journalier d'activité chez quelques Crocidurinae africains et européens (Soricidae, Insectivora). Rev. Ecol. (Terre Vie) 35: 97-108. 